\title{
Model perumusan kebijakan pendidikan
}

\author{
Henni Marsari $^{\left.{ }^{*}\right)}$, Sunita Hairani ${ }^{1}$, Nurhizrah Gistituati ${ }^{1}$ \\ ${ }^{1}$ Universitas Negeri Padang, Indonesia
}

\begin{tabular}{l} 
Article Info \\
\hline Article history: \\
Received Apr $11^{\text {th }}, 2021$ \\
Revised May $12^{\text {th }}, 2021$ \\
Accepted Jun $15^{\text {th }}, 2021$ \\
\hline
\end{tabular}

\section{Keyword:}

Kebijakan

Pendidikan

Perumusan

Analisis

\begin{abstract}
Perumusan kebijakan pendidikan sangat penting untuk dilaksanakan agar tujuan pendidikan yang telah disusun dapat dicapai secara maksimal. Untuk merumuskan kebijakan pendidikan maka perlu diketahui model-model perumusan kebijakan pendidikan tersebut. Tujuan penulisan artikel ini adalah untuk mengkaji dan menginformasikan model formulasi kebijakan pendidikan agar dapat dijadikan solusi dalam melahirkan kebijakan pendidikan. Metodologi penulisan ini menggunakan studi kepustakaan. Penulisan artikel ini dilakukan dengan mengkaji sebanyak 26 artikel nasional yang berhubungan dengan kebijakan pendidikan yang terdapat pada database google scholar.. Dari hasil pengkajian ditemukan beberapa model perumusan kebijakan pendidikan yaitu model kelembagaan, model sistem, model penyelidikan,model elit, model rasional, model inkrementalis, model analisis kebijakan, dan model pendekatan implementasi kebijakan publik. Pengkajian ini juga menemukan bahwa model perumusan kebijakan yang tepat digunakan di Indonesia adalah model analisis kebijakan pendidikan dan model implementasi kebijakan publik.
\end{abstract}

(C) 2021The Authors. Published by IICET.

This is an open access article under the CC BY-NC-SA license

(https://creativecommons.org/licenses/by-nc-sa/4.0)

\section{Corresponding Author:}

Henni Marsari,

Universitas Negeri Padang

Email: marsarihenni@gmail.com

\section{Pendahuluan}

Salah satu cara untuk meningkatkan kualitas pendidikan adalah dengan mengembangkan dan melaksanakan pendidikan secara maksimal (Mukhid, 2017). Secara umum pendidikan merupakan sebuah aktivitas yang direncanakan untuk mengembangkan pengetahuan, sikap dan keterampilan dengan tujuan untuk dapat meningkatkan kualitas hidup setiap warga negara (Bahri, 2017). Pendidikan pada hakikatnya penting untuk dilaksanakan oleh setiap warga negara. Hal ini dikarenakan pendidikan memiliki dampak yang besar bagi warga negara dan bangsa itu sendiri. Dengan meningkatnya pengetahuan, sikap dan keterampilan warga negara maka dengan sendirinya akan meningkatkan kualitas diri yang akan berdampak kepada peningkatan bangsa (Fitria, 2019). Pendidikan tidak dapat berdiri sendiri. Perlunya pihak penyelenggara yang dapat memfasilitasi jalannya pendidikan tersebut (Inah, 2013). Pada hal ini yang bertindak sebagai penyelenggara dalam proses pendidikan di sebuah negara adalah pemerintah. Pemerintah harus mampu menyelenggarakan pendidikan agar tercapainya tujuan pendidikan yang telah disepakati (Hakim, 2016).

Di indonesia penyelenggara pendidikan telah diatur diatur oleh UUD 1945 pasal 31 ayat 1,2,3 dan 3 yang intinya bahwa pendidikan merupakan hak seluruh warga negara. Warga negara berhak untuk dapat melaksanakan pendidikan yang di fasilitasi oleh negara. Selain itu dilahirkannya undang-undang khusus yang mengatur pendidikan yaitu UU No 20 Tahun 2003 tentang sistem pendidikan nasional membuktikan bahwa pemerintah Indonesia memiliki keseriusan dalam mengelola pendidikan warga negara. Selain itu banyaknya 
peraturan perundang-undangan, keputusan presiden, keputusan mentri dan lain-lainnya membuktikan bahwa pemerintah Indonesia bersungguh-sungguh untuk melaksanakan pendidikan bagi warga negara.

Dengan hal ini membuktikan bahwa pemerintah Indonesia dalam mengelola dan mengatur pendidikan di Indonesia dengan mengeluarkan kebijakan-kebijakan. Kebijakan-kebijakan ini yang dapat di implementasikan dalam proses pelaksanaannya. Kebijakan merupakan sebuah keputusan formal dalam organisasi yang bersifat tertulis, mengikat dan mengatur segala bentuk prilaku yang bertujuan untuk menghasilkan nilai-nilai baru dalam kehidupan warga negara (Ramdhani, 2017). Kebijakan ini yang dapat dijadikan referensi utama bagi warga negara maupun anggota organisasi dalam berperilaku. Pada hakikatnya sebuah kebijakan harus bersifar proaktif dan problem solving (Istanti, 2019). Hal inilah yang membedakan antara hukum dan peraturan. Sebuah kebijakan bersifat interpretatif dan adaptif. Kebijakan juga dapat mencirikan proses lokal yang khas namun dapat diterapkan secara umum serta memberikan kesempatan untuk menginterpertasikan detail yang ada.

Kebijakan biasanya digunakan oleh aktor dan intitusi organisasi pemerintah dalam kegiatan-kegiatan yang berhubungan dengan sistem pemerintah(Simanjutan, 2015). Banyak yang menghubungkan kebijakan dengan politik dikarenakan kebijakan berhubungan dengan tindakan politis dan konsekuensi politik (Aziz et al, 2020). Maka ada pernyataan bahwa kebijakan merupakan alat untuk mencapai tujuan (a means to an end).

Pencapaian tujuan yang berhubungan dengan masyarakat pada umumnya (public) akan memerlukan sebuah kebijakan publik (Suryono, 2014). Dalam sebuah kebijakan publik akan berlaku lingkaran kebijakan publik yang disebut dengan public cycle yang terdiri dari agenda setting, policy formulation, policy implementation, policy evaluation, policy change, dan policy termination (McPhail, 2003). Namun juga ada yang berpendapat bahwa kebijakan publik terdiri dari perancangan agenda, merumuskan kebijakan, pengadopsian kebijakan, pelaksanaan kebijakan dan penilaian kebijakan. Setiap tahapan yang ada harus diperhatikan dengan maksimal. Tahapan ini memaknai bahwa setiap kebijakan yang dibuat dilakukan tahapan dan proses yang dikontrol agar dapat menghasilkan kebijakan yang tepat sasaran (Alamsyah et al, 2020).

Namun kenyataan dilapangan ditemukan bahwa kebijakan yang dilaksanakan tidak berdasarkan tahapan yang telah ditetapkan. Hal ini menjadi pengingat bagi pemangku kebijakan agar dapat menghasilkan kebijakan dengan perumusan yang baik agar dapat memecahkan permasalahan yang ada. Berdasarkan hasil referensi dan studi literatur yang penulis lakukan bahwa analisis kebijakan dapat digambarkan melalui beragam disiplin ilmu pengetahuan, (Aziz et al, 2020). Maka diperlukan kajian khusus mengenai kebijakan di bidang pendidikan. Analisis model kebijakan di bidang pendidikan sangat perlu untuk dikembangkan dikarenakan agar dapat mencapai tujuan pendidikan yang telah ditetapkan. Ada banyak jenis model perumusan kebijakan dalam dunia pendidikan dalam memecahkan permasalahan yang berhubungan dengan pendidikan. Oleh sebab itu penulis tertarik untuk mengkaji dan menginformasikan model formulasi kebijakan pendidikan agar dapat dijadikan solusi dalam melahirkan kebijakan pendidikan.

\section{Metode}

Metodologi penulisan ini menggunakan metodologi studi kepustakaan. Penulisan artikel ini dilakukan dengan mengkaji sebanyak 26 artikel nasional yang berhubungan dengan kebijakan dan pengambilan keputusan yang terdapat pada database google scholar. Hasil dari pengkajian kemudian di jabarkan melalui artikel ilmiah.

\section{Hasil dan Pembahasan}

Ada beberapa model perumusan kebijakan pendidikan yaitu model kelembagaan, model sistem, model penyelidikan, model rasional, model inkrementalis, model analisis kebijakan, dan model pendekatan implementasi kebijakan publik. Adapun pembahasannya sebagai berikut:

\section{Model Kelembagaan}

Model kelembagaan ini berprinsip bahwa pemerintah adalah penanggung jawab pembuatan kebijakan, (Wibowo, 2013). Apapun yang dihasilkan oleh pemerintah merupakan kebijakan publik. Model kelembagaan ini didasari oleh fungsi kelembagaan dari setiap sektor pemerintah dalam merumuskan kebijakan, (Nurain et al, 2016). Pemberian kebijakan oleh pemerintah dicirikan dengan lembaga negara memberikan legitimasi, kebijakan negara bersifat universal dan kebijakan tersebut dapat dimonopoli dan dipaksakan oleh pemerintah kepada masyarakat. Hal ini selaras dengan pendapat yang menyatakan bahwa model lembaga merupakan model yang digunakan oleh pemerintah dalam merumuskan kebijakan (Fatem, 2020). Maka oleh sebab itu model kelembagaan ini dapat diterapkan dalam merumuskan kebijakan pendidikan di sektor pemerintah. 
Berdasarkan pengkajian yang penulis lakukan ditemukan bahwa model kelembagaan ini memiliki keunggulan yaitu pemerintah dapat menuntun masyarakat untuk dapat melaksanakan kebijakan melalui kekuatan dan monopoli kekuasaan yang sah. Namun model ini juga memiliki kelemahan yaitu model ini tidak memperhatikaan hubungan antar lembagai dan substansi dari kebijakan itu sendiri.

\section{Model Sistem}

Model sistem ini dikembangkan oleh ahli yang bernama Paine dan Naumes, (Triastuti, 2003). Model sistem merupakan model yang menggambarkan kejadian nyata yang terjadi saat pembuatan kebijakan. Model sistem ini disebut juga dengan model deskriptif. Model sistem ini dirumuskan dari sudut pandang pembuat kebijakan. Dalam merumuskan kebijakan dengan model ini pembuat kebijakan dilihat perannya dari proses perancangan maupun pengkoordinasian dalam menemukan pemecahan masalah yang akan 1) memformulasikan kesempatan dan menggunakan bantuan dari aspek internal maupun aspek internal, 2) memberikan kepuasan sesuai dengan permintaan lingkungan, dan 3) dapat memberikan kepuasan terhadap pembuat kebijakan, (Paiane and Naumes, 1975).

Model sistem mendeskripsikan bahwa adanya interaksi antara pembuat kebijakan dan lingkungan sebagai hal yang dinamis. Interaksi tersebut dapat berbentuk inputs dan outputs. Outputs yang dihasilkan akan menjadi bahagian dari lingkungan yang akan melakukan interaksi dengan organisasi. Model sistem mempercayai bahwa kebijakan politik yang timbul dari interaksi dianggap sebagai masukan sedangkan yang dikeluarkan merupakan respon dari setiap tuntutan yang dianggap sebagai luaran sistem politik. Agar setiap tuntutan dapat menjadi kebijakan maka diperlukan penyelesaian dari pihak-pihak yang bertentangan. Maka sebuah sistem dapat dibangun dari aspek-aspek yang mendukung sistem tersebut. Selain itu juga di dukung oleh sub sistem yang salin berhubungan (Walukow, 2012). Dengan saling berinteraksinya sebuah sistem maka sistem tersebut akan menghasilkan luaran yang jelas, memiliki akar-akar sistem yang kuat, dan memiliki penggunaan yang bersifat otoritas, (Toha dan Himy, 2020). Maka dari penjabaran model sistem tersebut maka model sistem dapat di aplikasikan pada kebijakan pendidikan namun perlu adnaya keikutsertaan masyarakat secara menyeluruh agar dapat memetakan permasalahan untuk dicarikan solusi yang tepat.

Berdasarkan kajian yang penulis lakukan ditemukan bahwa model sistem memiliki kelebihan yaitu memiliki input dan proses yang jelas dan sesuai prosedur sehingga menghasilkan output yang jelas. Sedangkan efisiensi waktu menjadi kelemahan dari model ini dikarenakan membutuhkan waktu yang banyak dalam menampun input dan melaksanakan proses sebelum dilahirkannya kebijakan

\section{Model Penyelidikan Campuran}

Model penyelidikan campuran disebut juga dengan model mixed scanning yang menggunakan aspekaspekdari dua pendekatan maupun dua sudut pandang. Model penyelidikan campuran menuntut pembuat kebijakan untuk menggunakan teori rasional yang bersifat menyeluruh dan inkrementalisme dengan memperhatikan situasi dan kondisi yang berbeda, (Mulyana et al, 2019). Pada beberapa kasus penggunaan pendekatan inkrementalisme sangat tepat untuk digunakan namun pada kasus lainnya pendekatan yang bersifat komprehensif lebih tepat untuk digunakan. Penggunaan model penyelidikan campuran dapat digunakan pada proses kebijakan pendidikan dengan mengambil keputusan yang dilakukan secara inkremental dan rasional (Ismail, 2016).

Berdasarkan kajian yang peneliti lakukan ditemukan bahwa model penyelidikan campuran memiliki kelebihan yaitu melihat dari dua sisi utama dan khusus dalam merumuskan kebijakan sehingga kebijakan yang ditemukan lebih terperinci namun hal ini menjadi kelemahan karena pembidikan permasalahan tersebut hanya difokuskan kepada beberapa daerah saja sehingga banyak daerah yang akan luput dari pantuan.

\section{Model Proses}

Model proses mengansumsikan bahwa politik merupakan kegiatan yang memiliki proses. Adapun tahapan perumusan kebijakan dengan model proses yaitu mengindentifikasi masalah, menyusun agenda, merumuskan perancangan kebijakan, pengesahan kebijakan, penerapan kebijakan, dan penilaian kebijakan, (Thomas, 2011). Penerapan model proses ini dalam kebijakan pendidikan dapat dilaksanakan dengan mengikuti setiap tahapan agar mendapatkan kebijakan yang tepat.

Berdasarkan kajian yang peneliti lakukan ditemukan bahwa model proses memiliki kelebihan yaitu kebijakan yang lahir merupakan bentuk kefokusan terhadap elemen irasinal perumus kebijakan dengan memperhatikan setiap kebutuhan masyarakat namun yang menjadi kelemahanya adalah membutuhkan waktu yang lama hingga kebijakan dapat di sahkan.

\section{Model Teori Elite}

Teori elite mengasumsikan bahwa masyarkat terdiri dari dua kelompok yaitu kelompok pemegang kekuasaan (penguasa/ elite) dan kelompok yang tidak memegan kekuasaan (masa),(Suryono, 2014). Teori elite ini berpadangan bahwa demokrasi yang dijalankan secara penuh akan memumngkinkan adanya bias dalam 
merumuskan kebijakan. Hal ini dikarenakan kebijakan yang dihasilkan merupakan bagian dari prefensi politik kaum elite, (Sjoraida, 2017). Model ini lebih banyak mempertimbangkan kepentingan elit dibandingkan tuntutan dari masyarakat. Maka isu kebijakan yang akan dimasukan dalam proses perumusan kebijakan pendidikan menjadi hasil konflik dan kesepakatan dari kaum elit politi tersebut sedangkan masyarakat tidak memiliki kekuatan untuk dapat mencampuri kebijakan yang dihasilkan. Oleh sebab itu perlunya kebijaksanaan kaum elit politik untuk dapat merumuskan kebijakan yang berlandasan kepentingan umum.

Berdasarkan kajian yang peneliti lakukan ditemukan bahwa model elit memiliki kelebihan bahwa kebijakan yang dihasilkan lebih cepat yang dilandasi dengan konsep dan teori pakar ahli namun kebijakan tersebut tidak di tampung dari bawah sehingga masyarakat hanya mengetahui bahwa kebijakan telah ada dan wajib untuk dilaksanakan.

\section{Model Rasional}

Model rasional merupakan kebijakan yang didapatkan dari perolehan sosial maksimum. Artinya bahwa model rasional yang digunakan oleh pemerintah harus mampu untuk menghasilkan kebermanfaatan yang maksimal bagi masyarakat, (Latifa, 2016). Teori ini mempreskripsikan berbagai bentuk prosedur dalam mengambil keputusan yang diperoleh dari cara yang dianggap effisien dalam merumuskan kebijakan. Model rasional berasal dari pemikiran rasionalisme dan positifisme yang bersifat ilmiah, (Susanto, 2016). Hal ini dikarenakan model rasional meyakini bahwa permasalahan yang dihadapi dapat diselesaikan melalui metode yang ilmiah dan rasional. Maka dapat disimpulkan bahwa keputusan publik tidak mengoptimalkan manfaat diatas bebas namun hanya memenuhi kriteria pembuat kebijakan sedangkan rasionalitas manusia memiliki keterbatasan.

Berdasarkan kajian yang peneliti lakukan ditemukan bahwa model rasional memiliki keleibihan yaitu kebijakan yang akan dilahirkan sesuai dengan kondisi dilapangan namun model ini memiliki kelemahan yaitu keterbatasan rasional intelektual dari sipembuat kebijakan.

\section{Model Inkrementalis}

Model inkrementalis merupakan bentuk dari kritik model rasional. Model ini beranggapan bahwa pembuat kebijakan tidak memungkinkan melaksanakan proses seperti model rasional dikarenakan adanya keterbatasan pada pembuat kebijakan seperti keterbatasan waktu, intelektual dan biaya, (Handrian et al, 2021). Model ini melakukan penyesuaian dengan realitis kehidupan demokratis dan pluralitas serta keterbatasan yang dimiliki manusia. Model ini berlandasan bahwa adanya perubahan inkrementalis mengakibatkan adanya proses keamanan apabila terjadinya perubahan kebijakan. Segala bentuk pengetahuan yang dipercaya dilandaskan kepada satu-satunya acara untuk memperoleh keputusan tanpa memunculkan resiko, (Maulana et al, 2018). Maka secara umum dapat disimpulkan bahwa model inkrementalis merupakan model yang yang tidak melakukan proses sehingga kurang tepat digunakan dalam proses perumusan kebijakan dikarenakan kebijakan dalam pendidikan bersifat kontiniu dan memakan waktu yang lama.

Berdasarkan kajian yang peneliti lakukan ditemukan bahwa model inkremantalis memiliki kelebihan yaitu kebijakan yang dilahirkan lebih cepat karena kebijakan yang dilahirkan merupakan kebijakan yang dianggap paling tepat tanpa memikirkan alternatif lainnya namun yang menjadi kelemahanya adalah kebijakan hanya dapat diterapkan pada permasalahan yang bersifat rutin.

\section{Model Analisis Kebijakan Pendidikan}

Model analisis kebijakan merupakan suatu upaya dalam memperoleh dan menghasilkan kebijakan melalui proses argumentasi dan metode inkuiri dalam pendekatan disiplin ilmu sosial terapan dengan pengambilan keputusan politis dalam upaya memecahkan permasalahan dalam sebuah kebijakan,(Chabibi, 2019). Proses analisis dimanfaatkan untuk menggunakan pengetahuan dan pemahaman dasar dalam memecahkan permasalahan yang tidak hanya sekedar argumentasi. Model ini terdiri dari 3 bentuk yaitu model prospektif, model retrospektif dan model integratif. Model prospektif merupakan model analisis yang dilakukan sebelum sebuah kebijakan di implementasikan, (Igbal and Salomo, 2018). Model retrospektif merupakan model analisis kebijakan yang dilakukan setelah kebijakan tersebut diterapkan. Model integratif merupakan model yang menggabungkan kedua analisis kebijakan sebelumnya. Model ini disebut juga dengan model analis holistic atau komprehensif. Artinya model ini melakukan analisis sebelum dan sesudah kebijakan tersebut di implementasikan. Maka dalam kebijakan pendidikan diperlukan analisis yang dilakukan secara menyeluruh baik sebelu dan sesudah kebijakan tersebut di implementasikan.

Berdasarkan kajian yang peneliti lakukan ditemukan bahwa model ini memiliki kelebihan bahwa kebijakan yang dihasilkan sesuai dengan permasalahan yang dihadapi oleh masyarkat namun kebijakan ini akan membutuhkan biaya dan tenaga yang banyak. 
Model Pendekatan Implementasi Kebijakan Publik

Model pendekatan Implementasi kebijakan publik terdapat dua pendekatan kontrol dan komando (top down) serta pendekatan pasar (bottom up), (Nasiri and Hermawan, 2017). Pendekatan ini mengacu kepada model kerangka kerja yang saling berhubungan antara kebijakan dan hasilnya. Pendekatan top down merupakan pendekatan yang dilahirkan dari tingkat atas (pusat) sedangkan pendekatan buttom up lebih bersifat rasional, (Akib, 2012). Model ini diasumsikan sebagai sebuah alur maupun proses. Model ini memandang proses dari perubahan politik dan sosial yang mana kebijakan yang dibuat oleh pemerintah merupakan hal untuk memperbaiki permasalahan yang terdapat pada masyarakat. Maka dapat penulis simpulkan bahwa penerapan model ini harus disesuaikan dengan kebutuhan serta tujuan yang akan dicapai dalam pengimplementasian pada dunia pendidikan.

Dari penjelasan mengenai model perumusan kebijakan pendidikan tersebut maka dapat kita lihat terdapat banyak model yang bisa digunakan dalam merumuskan kebijakan pendidikan. Masing-masing model memiliki kekuatan dan kelemahan yang bisa kita maksimalkan agar dapat melahirkan kebijakan yang tepat dengan sasaran.

Namun berdasarkan kajian penulis model yang tepat digunakan adalah model analisis kebijakan pendidikan dan model implementasi kebijakan publik. Hal ini dikarenakan bahwa kedua model tersebut menghasilkan kebijakan menggunakan metode saintifik. Artinya bahwa kebijakan tersebut lahir dari metode ilmiah. Sebelum kebijakan dilahirkan, pembuat kebijakan akan menghimpun data dari hal yang mendasar hingga hal yang lebih luas sehingga data yang dimiliki lebih komprehensif. Pada saat proses perumusan kebijakan juga dilakukan uji coba secara saintifik sehingga pada proses uji coba tersebut didapatkan kelemahan-kelemahan yang dapat diperbaiki. Selain itu juga ada bentuk evaluasi terpadu yang digunakan untuk menilai keberhasilan kebijakan tersebut.

\section{Simpulan}

Perumusan kebijakan pendidikan sangat penting untuk dilaksanakanagar tujuan pendidikan yang telah disusun dapat dicapai secara maksimal. Untuk merumuskan kebijakan pendidikan maka perlu diketahui model-model perumusan kebijakan pendidikan tersebut. Ada beberapa model perumusan kebijakan pendidikan yaitu model kelembagaan, model sistem, model penyelidikan, model rasional, model inkrementalis, model analisis kebijakan, dan model pendekatan implementasi kebijakan publik. Masingmasing model kebijakan dapat memiliki kekuatan dan kelemahan. Namun kekuatan dan kelemahan tersebut dapat kita sesuaikan dengan kondisi perumusan kebijakan tersebut. Selain itu berdasarkan kajian ditemukan model analisis kebijakan pendidikan dan model implementasi kebijakan publik merupakan model yang tepat untuk digunakan di Indonesia.

\section{Referensi}

Akib, H. (2012). Implementasi kebijakan: Apa, mengapa dan bagaimana. Jurnal Ilmiah Ilmu Administrasi Publik, 1(1), 1-11.

Alamsyah, K., Hidayat, T. R., \& Bustomi, T. (2020). Implementasi Kebijakan Deteksi Dini Pelayanan Dasar Masyarakat Di Kota Bekasi. Khazanah Multidisiplin, 1(2), 72-89.

Aziz, A. A., Nurfarida, R., Budiyanti, N., \& Zakiah, Q. Y. (2020). Model Analisis Kebijakan Pendidikan. Tapis: Jurnal Penelitian Ilmiah, 4(2), 192-201.

Bahri, S. (2017). Pengembangan Kurikulum Dasar dan Tujuannya. Jurnal Ilmiah Islam Futura, 11(1), 15-34.

Chabibi, M. (2019). Model Analisis Kebijakan Publik Dalam Program Beasiswa Santri Berprestasi Kemenag. Zawiyah: Jurnal Pemikiran Islam, 5(1), 135-152.

Fatem, S. M., Maryudi, A., Pudyatmoko, S., \& Marwa, J. (2020). Model Kelembagaan Lokal Kabupaten Konservasi Tambrauw di Papua Barat. Jurnal Ilmu Kehutanan, 14(2), 167-184.

Fitria, H., Kristiawan, M., \& Rahmat, N. (2019). Upaya Meningkatkan Kompetensi Guru Melalui Pelatihan Penelitian Tindakan Kelas. Abdimas Unwahas, 4(1),1-10

Hakim, L. (2016). Pemerataan akses pendidikan bagi rakyat sesuai dengan amanat Undang-Undang Nomor 20 Tahun 2003 tentang Sistem Pendidikan Nasional. EduTech: Jurnal Ilmu Pendidikan Dan Ilmu Sosial, 2(1), 1-10

Handrian, E., Rosmita, R., \& Khan, M. C. (2021). Model Inkremental: Evaluasi Program Peningkatan Kesempatan Kerja di Provinsi Riau. JIAP (Jurnal Ilmu Administrasi Publik), 9(1), 1-12.

Inah, E. N. (2013). Peranan komunikasi dalam pendidikan. Al-TA'DIB: Jurnal Kajian Ilmu Kependidikan, 6(1), 176-188. 
Iqbal, A. M., \& Salomo, R. V. (2018). Analisis Kebijakan Pengenaan Pajak atas Bahan Bakar Minyak Bersubsidi Minyak Solar. Transparansi: Jurnal Ilmiah Ilmu Administrasi, 1(1), 1-11.

Ismail, M. H., \& Sofwani, A. (2016). Konsep dan Kajian Teori Perumusan Kebijakan Publik. JRP (Jurnal Review Politik), 6(2), 195-224.

Istanti, D. J. (2019). Dinamika Kebijakan Kurikulum Pendidikan di Indonesia Pasca Reformasi. Jurnal Ilmu Politik dan Pemerintahan, 5(2), 140-156.

Latifa, A. (2016). Aplikasi Model Pengambilan Keputusan Dalam Perilaku Fertilitas. Jurnal Kependudukan Indonesia, 5(1), 55-73.

Maulana, H. F., Mayunita, S., Hastuti, H., \& Wijaya, A. A. M. (2018). Diskurusus Kebijakan Publik Model Incremental. Kybernan: Jurnal Studi Kepemerintahan, 1(2), 1-13.

McPhail, B. A. (2003). A feminist policy analysis framework: Through a gendered lens. The Social Policy Journal, 2(2-3), 39-61.

Mukhid, A. (2017). Meningkatkan kualitas pendidikan melalui sistem pembelajaran yang tepat. TADRIS: Jurnal Pendidikan Islam, 2(1).

Mulyana, Y., Huraerah, A., \& Martiawan, R. (2019). Kebijakan pengembangan destinasi pariwisata Cianjur Selatan di Kabupaten Cianjur Jawa Barat. JISPO Jurnal Ilmu Sosial dan Ilmu Politik, 9(1), 490-511.

Nasirin, C., \& Hermawan, D. (2017). Kontroversi Implementasi Kebijakan Penenggelaman Kapal Dalam Rangka Pemberantasan Illegal Fishing di Indonesia. Spirit Publik, 12(1), 9-24.

Nuraini, C., Darwanto, D. H., Masyhuri, M., \& Jamhari, J. (2016). Model Kelembagaan pada Agribisnis Padi Organik Kabupaten Tasikmalaya. AGRARIS: Journal of Agribusiness and Rural Development Research, 2(1), 9-16.

Paine, F. T., \& Naumes, W. (1975). Organizational strategy \& policy. Saunders.

Ramdhani, A., \& Ramdhani, M. A. (2017). Konsep umum pelaksanaan kebijakan publik. Jurnal Publik, 11(1), $1-12$.

Simanjuntak, K. M. (2015). Implementasi kebijakan desentralisasi pemerintahan di Indonesia. Jurnal Bina Praja: Journal of Home Affairs Governance, 7(2), 111-130.

Sjoraida, D. F. (2017). Urgensi unsur elit dalam pelaksanaan kebijakan informasi publik di jawa barat. JWP (Jurnal Wacana Politik), 2(2), 1-10.

Suryono, A. (2014). Kebijakan publik untuk kesejahteraan rakyat. Transparansi: Jurnal Ilmiah Ilmu Administrasi, 6(2), 98-102.

Susanto, R. (2016). Hubungan Pengambilan Keputusan Rasional Dengan Akuntabilitas Kepemimpinan Kepala Sekolah. Eduscience: Jurnal Ilmu Pendidikan, 2 (1), 22, 39.

Thomas R. (2011). Understanding Public Policy. New Jersey: Prentice Hall.

Toha, M., \& Hilmy, M. (2020). Pendidikan Islam di Kota Metropolis: Studi Kebijakan Penyelenggaraan PAI di Surabaya. Inteligensia Media.

Triastuti, M. R. H. (2003). Analisis Formulasi Kebijakan Kenaikan Tarif Listrik, Telepon dan BBM di Tahun 2003: Disintegrate System Model of Public Policy Toward Organizational Learning and Policy Change. Jurnal Administrasi Publik, 2(1), 1-10.

Walukow, A. F. (2012). Analisis Kebijakan Penurunan Luas Hutan Di Daerah Aliran Sungai Sentani Berwawasan Lingkungan (Environmental Based of Policy Analysis About the Decrease of Forest Area in Sentani Watershed). Jurnal Manusia dan Lingkungan, 19(1), 74-84.

Wibowo, L. R. (2013). Analisis Kebijakan Publik Pengembangan Model Kelembagaan Kompensasi Das Ciliwung (Public policy analysis on the development of a compensation institution model at Ciliwung Watershed). Jurnal Manusia dan Lingkungan, 20(3), 353-366 